\title{
Effects of HBV and HCV infection on oxidative stress and inflammation in hemodialysis patients
}

\author{
${ }^{1}$ EMRE AVCI \\ ${ }^{2}$ MERVE GELDI \\ ${ }^{3}$ GULCIN ALP AVCI* \\ ${ }^{4}$ SULE COSKUN CEVHER \\ ${ }^{1}$ Faculty of Science and Arts, Department of \\ Molecular Biology and Genetics, Molecular Biology \\ and Biochemistry, Hitit University, Corum, TURKEY, \\ avci.emre@yahoo.com \\ ${ }^{2}$ Institue of Science, Department of Biology, Hitit \\ University, Corum, TURKEY, \\ mervegeldi87@gmail.com \\ ${ }^{3}$ Faculty of Science and Arts, Department of \\ Molecular Biology and Genetics, Molecular \\ Microbiology and Biotechnology, Hitit University, \\ Corum, TURKEY, alp.gulcin@yahoo.com \\ ${ }^{4}$ Faculty of Science and Arts, Department of Biology, \\ Gazi University, Ankara, TURKEY, sule@gazi.edu.tr

\section{*Correspondence:} \\ Gulcin ALP AVCI \\ E-mail: alp.gulcin@yahoo.com; gulcinalp@hitit.edu.tr
}

Keywords: Chronic renal failure, HBV, HCV, 3-NT, TWEAK, HSP70
Received August 01, 2017.

Revised January 21, 2018.

Accepted February 06, 2018.

\begin{abstract}
Background and purpose: Chronic renal failure is a syndrome characterized by progressive and irreversible loss of nephrons depending on various diseases. Especially infection such as $H B V$ and $H C V$ is among the major causes of mortality and morbidity in hemodialysis patients. In the present study we aimed to determine the levels of 3-nitrotyrosine (3-NT), TNF-like weak inducer of apoptosis (TWEAK) and heat shock protein (HSP70) in chronic renal failure patients diagnosed with $\mathrm{HBV}, \mathrm{HCV}$ and non-hepatitis undergoing hemodialysis treatment.
\end{abstract}

Materials and methods: Samples of 235-patients receiving hemodialysis treatment and 25-healthy individuals were included in the study. Firstly, HBV and HCV positivity were diagnosed by serological EnzymeLinked ImmunuSorbent Assay (ELISA) method. Then, 3-NT levels were determined using High-Performance Liquid Chromatography (HPLC), while TWEAK and HSP7O were determined using high sensitivity ELISA. The numbers of patients used in the studies were determined according to statistical power analysis.

Results: The values of 3-NT and HSP7O were found to be significantly higher non-hepatitis patients, $H B V$ and HCV patients receiving hemodialysis treatment to compared with the control group $(p<0.05)$. Concentration of TWEAK in non-hepatitis and HBV patients receiving hemodialysis therapy was found to be significantly higher to compared with the control group (pr0.05). However, unlike the other two groups, an increase in the TWEAK of HCV patients on post-dialysis was determined.

Conclusions: To prevent the increase of inflammation and oxidative stress in hemodialysis patients or to keep it under control, investigating certain parameters such as TWEAK, 3-NT and HSP7O from time to time is of great importance in terms of minimizing the level of risk for many diseases such as cardiovascular diseases. Infection also increases the burden on oxidative stress and immunity system in these patients.

\section{INTRODUCTION}

Some changes occur in several clinical and laboratory findings in $S_{\text {patients due to loss of in the kidneys. These findings increase based }}$ on how progressive the loss of function is and they are classified into four stages (1). Terminal period, the fourth one, is the uremia and during this period, patients need renal replacement therapies such as dialysis or transplantation. Hemodialysis patients in the terminal stage are quite susceptible to various infections, particularly viral infections, particularly (2). Hepatitis B (HBV) and hepatitis C (HCV) viruses which 
are major health problems in all societies are also seen frequently in hemodialysis patients. everal factors are known to be associated with increased risk of $\mathrm{HBV}$ and HCV infections. Duration on HD is well recognized as a important predisposing factor for HBV and HCV. It is estimated that over two billion people are infected with $\mathrm{HBV}$ on the worldwide (3). Compared with other viruses transmitted by blood, HBV is highly contagious (5). However, approximately 1.75 million people were newly infected with HVC in 2015, thus bringing the global total of people living with HCV to 71 million (4-6). In studies conducted in recent years, it has been reported that HBV and HCV infections have a high incidence in patients undergoing chronic hemodialysis therapy (2, 7-10). This is both due to the weak immune systems and a large number of parenteral interventions during treatment $(7,8)$. Especially, they do not respond sufficiently to vaccinations thymus-dependent antigens, such as HBV (1, 9-11). The most important ways of transmission of $\mathrm{HCV}$ in dialysis units are contaminated materials, insufficiently trained cleaning staff and vials being used on multiple patients (12). However, it is not known what precautions are taken to protect these patients from viral agents such as HBV and HCV (2). The longer the duration of dialysis in hemodialysis patients, the higher the frequency of $\mathrm{HBV}$ and $\mathrm{HCV}$ incidence rises significantly in the same way (13-15). A major chronic reduction in antioxidant systems and an increase in the formation of oxygen free radicals are both encountered in dialysis patients and in patients with hepatitis (16). It is observed that free oxygen radicals are overproduced in organisms, while antioxidant mechanism remains inadequate, disrupting the balance which means that oxidative stress occurs. Studies in recent years indicate that the increased oxygen free radicals and lipid peroxidation play a part in the development of many diseases (17-19). Normally antioxidant defense and reactive oxygen species in the human body are in balance. Intensive production of reactive oxygen species or the decline of antioxidant defense creates oxidative stress by causing structural and functional changes in biomolecules $(19,20)$. Studies conducted so far suggest, it has been seen that hemodialysis therapy applied for end-stage chronic renal failure patients leads to increased oxidative stress (21-23). In recent years, 3-nitrotyrosine (3-NT) is used as a marker to evaluate potential cytotoxic effects of NO in the organism. Peroxynitrite $(\mathrm{NO}-)$ is a cytocidal derivative occurring as a result of reactions of with nitric oxide $(\mathrm{NO})$ and $\mathrm{O}_{2}$ in the living beings (24). Another important marker for oxidative stress and immunity is the TNF-like weak inducer of apoptosis (TWEAK), a member of the TNF family. It has many functions similar to TNF- $\alpha$. TWEAK in cytokine family is stimulates apoptosis, while at the same time it induces inflammation and cell growth. Another marker exhibiting an increase under stress heat shock protein HSP70. The increase occurring in HSP70 offers protection for cell culture and animal tissues (25). Also, HSP70 helps proteins to be transported in cells and has a function in the folding of proteins synthesized within the cell and it is responsible for the destruction of unstable proteins as well as preventing protein aggregation and it also helps protein folding refold when damaged and apoptosis (26).

In our study, in addition to investigating the prevalence of viral infections ( $\mathrm{HBV}$ and $\mathrm{HCV}$ ), one of the major problems encountered in hemodialysis patients receiving dialysis treatment due to chronic renal failure, we also aimed to evaluate the effect of infection on oxidative stress and protein oxidation. For this purpose, 3-NT, TWEAK and HSP70 levels were investigated in the control group and chronic renal failure patients on hemodialysis therapy.

\section{MATERIALS AND METHODS}

\section{Patients Selection Criteria}

Ethical approval for the study was obtained from local ethics committee (University of OMU Protocol No. 107/2012). Two hundred thirty-five patients receiving hemodialysis therapy due to chronic renal failure in Corum private dialysis centers were involved in the study. The numbers of patients with HBV and HCV infections and non-hepatitis receiving hemodialysis treatment included in the study were based on the power analysis. The patients were classified into different groups based on the presence of viral coinfections as well.. Serum samples of 235 patients receiving hemodialysis treatment due to chronic renal failure and 25 individuals as healthy control group were included in the study. Patients included in this analysis ranged in age from 25 to 65 years old, with a median age of 45 . Serum was obtained by centrifugation of whole blood at $3000 \mathrm{rpm}$ for $10 \mathrm{~min}$ and aliquots were stored at $-80{ }^{\circ} \mathrm{C}$ until assayed.

\section{Diagnosis of HVC and HBV infections}

$\mathrm{HBV}$ and $\mathrm{HCV}$ positivity were determined by serological ELISA method. HBsAg ELISA kits (ABOTT PRISM HBsAg, USA) for HBV and Murex anti-HCV ELISA kits (ABBOTT murex, South Africa) for HCV were used.

\section{Protein Damage Index: Determination of 3-nitrotyrosine levels}

Determination of 3-NT levels, the protein damage indicator in the serum sample of patients and healthy individuals included in the study, was done using HPLC (Immuchrom, Haasen, Germany) kit in HPLC system (High-Performance Liquid Chromatography).

\section{Determination of TWEAK and HSP7O levels}

High-sensitivity ELISA kit was used to determine the level of the Human TWEAK instant and Human soluble 
Table 1. 3-NT values $(\mu g / L)$ of non-hepatitis, HBV and HCV patients receiving hemodialysis treatment and control group

\begin{tabular}{|lccc|}
\hline Groups & n & Mean \pm S.D. & $\begin{array}{c}\text { 95\% Confidence } \\
\text { Interval for Mean } \\
\text { Min. - Max. }\end{array}$ \\
\hline Control & 25 & $13.08 \pm 4.65$ & $11.16-15.00$ \\
\hline HBV & & & \\
\hline Pre-HD & 25 & $124.62 \pm 33.65^{*}$ & $110.73-138.51$ \\
Post-HD & 25 & $21.72 \pm 7.46^{*}$ & $18.64-24.80$ \\
\hline HCV & & & \\
\hline Pre-HD & 25 & $257.22 \pm 25.05^{*}$ & $246.88-267.57$ \\
Post-HD & 25 & $34.80 \pm 17.25^{*}$ & $27.68-41.92$ \\
\hline Non-Hepatitis & & \\
\hline Pre-HD & 25 & $211.16 \pm 35.88^{*}$ & $196.35-225.97$ \\
Post-HD & 25 & $42.03 \pm 16.12^{*}$ & $35.37-48.68$ \\
\hline
\end{tabular}

HD; Hemodialysis

Values are expressed as mean \pm S.D.

* Statistical significance level was determined as $\mathrm{p}<0.05$ when both control and intra-group comparisons were made. ( $\mathrm{p}=0.000$ for HBV, HCV and non-hepatitis)

HSP70 (Bendermed Diagnostic System, eBioscience, Austria, Avicer to, eBioscience, Inc., respectively).

\section{Statistical analysis}

Statistical analysis was performed using SPSS 20.0 software (IBM SPSS Inc. Chicago, IL, USA). All mea- surements were taken in triplicate. Data are reported as means \pm standard distribution (SD). After assessing the normality distribution (Shapiro-Wilk test) and homogeneity of variances, parametric $t$-test and ANOVA were used. In cases where these assumptions were not met, non-parametric Mann Whitney-U and Kruskal Wallis $\mathrm{H}$-tests were used for comparison of differences between means. The critical significance level for the statistical tests performed was set at 0.05 .

\section{RESULTS}

$\mathrm{HBV}$ and $\mathrm{HCV}$ positivity were investigated in all samples through ELISA method. According to the results, the rate of $\mathrm{HBV}$ was $22.5 \%(53 / 235)$, the rate of HCV was $10.6 \%$ (25/235), while $66.8 \%(157 / 235)$ of patients were not infected with HCV or HBV .

\section{Evaluation of 3-NT}

The level of 3-nitrotyrosine, which is the protein damage indicator, was found to be significantly higher nonhepatitis patients, hepatitis $B$ and hepatitis $C$ patients receiving hemodialysis treatment than the control group $(\mathrm{p}<0.05)$. 3-NT values of patients with HCV in pre-hemodialysis were found higher than those of HBV and non-hepatitis group. Although a significant decrease could be observed on post-dialysis when the pre and postdialysis 3-NT values were compared in all samples, still the values obtained were higher compared with the control group as indicated in Table 1 and Figure 1.

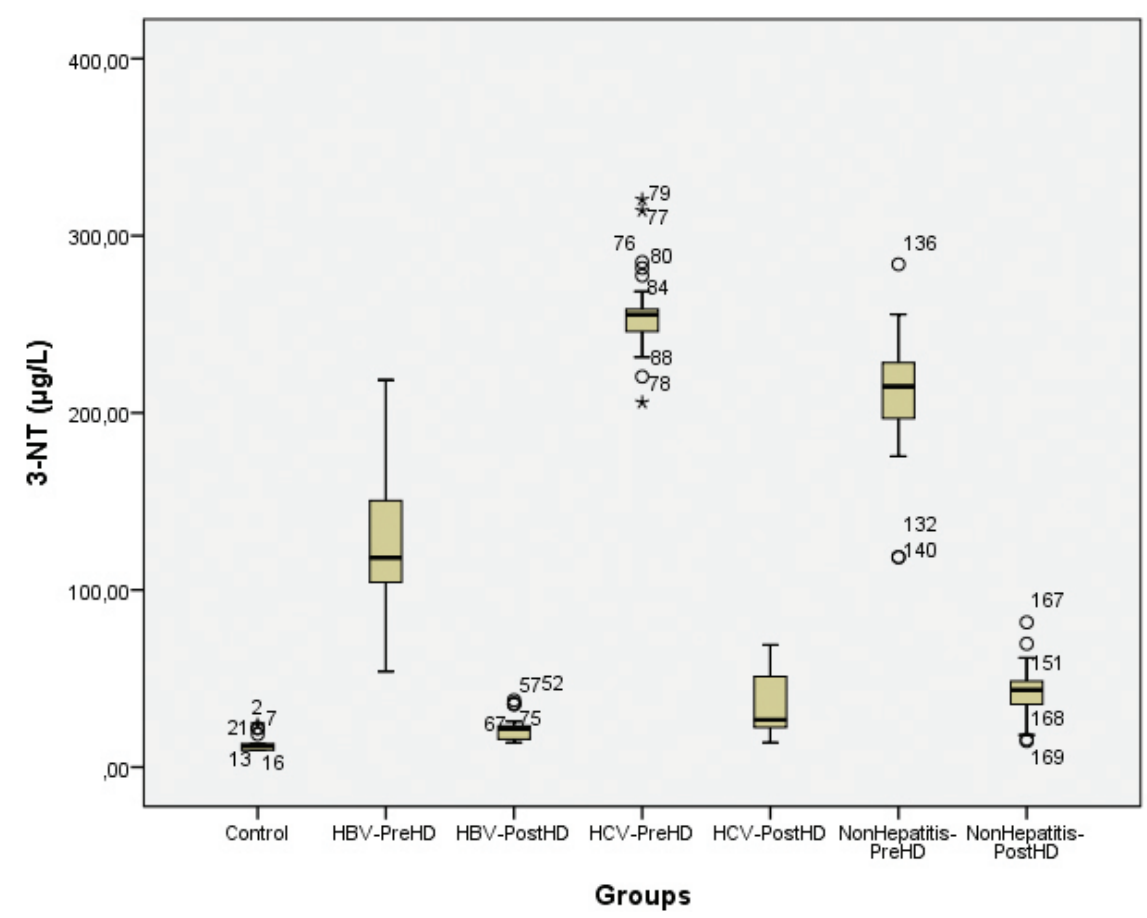

Figure 1. 3-NT levels, the protein damage index of non-hepatitis, hepatitis $B$ and hepatitis $C$ patients receiving hemodialysis treatment and control group. 
Table 2. TWEAK values ( $\mathrm{g} / \mathrm{ml}$ ) of non-hepatitis, $H B V$ and $H C V$ patients receiving hemodialysis treatment and control group

\begin{tabular}{|cccc|}
\hline Groups & n & Mean \pm S.D. & $\begin{array}{c}\text { 95\% Confidence } \\
\text { Interval for Mean } \\
\text { Min. - Max. }\end{array}$ \\
\hline Control & 25 & $335.7 \pm 49.2$ & $315.4-356.0$ \\
\hline HBV & & & \\
\hline Pre-HD & 25 & $773.8 \pm 452.6^{*}$ & $587.0-960.7$ \\
Post-HD & 25 & $380.8 \pm 68.8^{*}$ & $352.4-409.2$ \\
\hline HCV & & $181.2 \pm 54.9^{*}$ & $158.6-203.9$ \\
\hline Pre-HD & 25 & $462.2 \pm 140.7^{*}$ & $404.0-250.2$ \\
\hline Post-HD & 25 & & \\
\hline Non-Hepatitis & & & $892.4-1086.1$ \\
\hline Pre-HD & 25 & $989.2 \pm 234.6^{*}$ & $386.0-472.1$ \\
\hline Post-HD & 25 & $429.1 \pm 104.3^{*}$ & \\
\hline
\end{tabular}

HD; Hemodialysis

Values are expressed as mean \pm S.D.

* Statistical significance level was determined as $p<0.05$ when both control and intra-group comparisons were made. ( $\mathrm{p}=0.016$ for HBV, $\mathrm{p}=0.000$ for HCV and non-hepatitis)

\section{Evaluation of TWEAK}

TWEAK values in non- hepatitis and HBV patients receiving hemodialysis therapy were found to be significantly higher compared with controls $(\mathrm{p}<0.05)$. Although a significant decrease could be observed in non-hepatitis and HBV patients groups in post-dialysis when the pre and post-dialysis values were compared, the values could still be observed to be above the control group. However, unlike the other two groups, an increase in the TWEAK values of HCV patients on post-dialysis was determined. TWEAK values of all groups were given in Table 2 and Figure 2.

\section{Evaluation of HSP-70}

The HSP-70 values were found to be higher in nonhepatitis, $\mathrm{HBV}$ and $\mathrm{HCV}$ patients receiving hemodialysis therapy than those of control group. When pre and postdialysis values are compared, a minimal increase in postdialysis among $\mathrm{HBV}, \mathrm{HCV}$ and non-hepatitis patient groups was observed (Table 3, Figure 3). Statistical significance level was determined as $\mathrm{p}<0.05$ when both control and intra-group comparisons were made. But when the intra-group comparison was made, the statistical significance level was determined as $\mathrm{p}>0.05$ only on HBV group.

\section{DISCUSSION}

Hemodialysis is an effective treatment for most patients with renal failure and an alternative for kidney transplantation, thereby improving the quality of life of the patient with adequate dialysis and even prolongs the lifespan (27). However, among the most important factors leading to an increase in mortality rate and restricting the quality of life

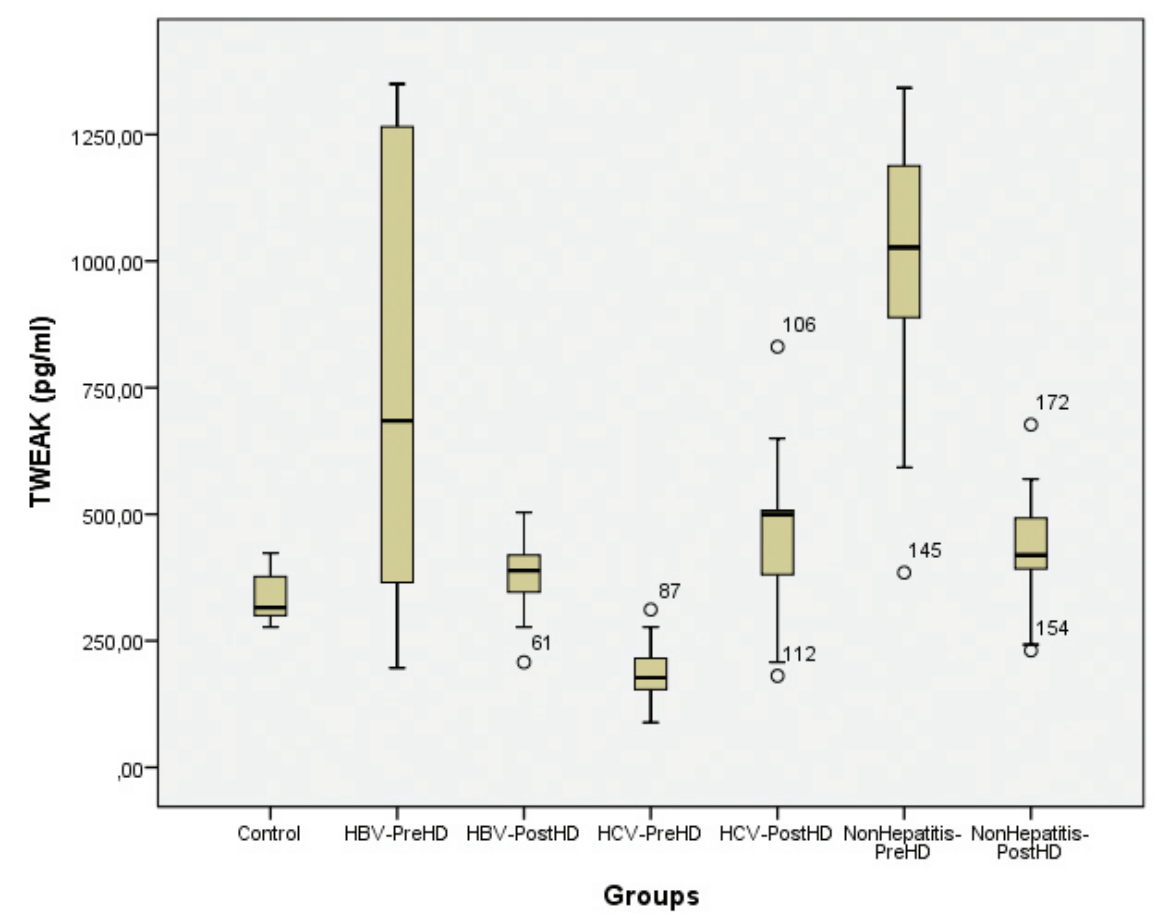

Figure 2. TWEAK levels of non-hepatitis, hepatitis $B$ and hepatitis $C$ patients receiving hemodialysis treatment and control group 
Table 3. $H S P-70$ values ( $\mathrm{pg} / \mathrm{ml}$ ) of non-hepatitis, $H B V$ and $H C V$ patients receiving hemodialysis treatment and control group

\begin{tabular}{|ccccc|}
\hline Groups & n & Mean \pm S.D. & $\begin{array}{c}\text { 95\% Confidence } \\
\text { Interval for Mean } \\
\text { Min. }- \text { Max. }\end{array}$ & p \\
\hline Control & 25 & $3.3 \pm 0.3$ & $3.2-3.4$ & \\
\hline HBV ${ }^{* *}$ & & & & \\
\hline Pre-HD & 25 & $11.8 \pm 2.6^{*}$ & $10.7-12.9$ & $*$ \\
Post-HD & 25 & $12.6 \pm 3.9^{*}$ & $11.0-14.5$ & $*$ \\
\hline HCV & & & & $*$ \\
\hline Pre-HD & 25 & $9.7 \pm 1.0^{*}$ & $9.3-10.2$ & $*$ \\
Post-HD & 25 & $10.8 \pm 1.7^{*}$ & $10.1-11.6$ & $*$ \\
\hline Non-Hepatitis & & & & $*$ \\
\hline Pre-HD & 25 & $9.9 \pm 1.3^{*}$ & $9.4-10.4$ & $*$ \\
\hline Post-HD & 25 & $10.8 \pm 1.4^{*}$ & $10.2-11.4$ & $*$ \\
\hline
\end{tabular}

HD; Hemodialysis

Values are expressed as mean \pm S.D.

* Statistical significance level was determined as $\mathrm{p}<0.05$ when both control and intra-group comparisons were made. ( $\mathrm{p}=0.011$ for $\mathrm{HCV}$ and $\mathrm{p}=0.031$ for non-hepatitis)

** But when the intra-group comparison was made, the statistical significance level was determined as $\mathrm{p}>0.05$ only on HBV group. ( $\mathrm{p}=0.751$ for $\mathrm{HBV})$

in dialysis patients during the dialysis are viral diseases. In particular, HBV and HCV are serious public health problems in the world; moreover, patients with chronic kidney disease are exposed to these infections at a very high rate $(7,8)$. The compromised immune systems of the dialysis patients with dialysis might lead to other disorders in other body functions. Vascular calcification and oxidative stress are widely encountered especially among patients receiving hemodialysis developing end-stage renal disease (ESRD). In addition to investigating the prevalence of viral infections (HBV and HCV), one of the major problems encountered in hemodialysis patients receiving dialysis treatment due to chronic renal failure, we also aimed to evaluate the effect of infection on oxidative stress and protein oxidation in this patient group through various parameters. For this purpose, by determining the 3-NT, TWEAK and HSP70 levels, these levels were compared both with the control and patient groups. The level of 3-NT, the oxidative stress indicator, in these patients was also investigated by Erdur et al. to determine the relationship between coronary artery calcification and oxidative stress in peritoneal dialysis and hemodialysis patients and it was found that the level of nitrotyrosine was higher compared to healthy individuals (28). Koleganova et al. immunohistochemically determined the level of TNF-alpha and nitrotyrosine in aortic samples of ESRD and control group. ESRD patients on TNF-alpha and nitrotyrosine levels were found to be significantly higher compared to the control group (29). In the results part of the study in which Köse et al aimed to determine the effects of hemodialysis and peritoneal dialysis treatments on of oxidative and nitrosative stress markers, they concluded that pre and post hemodialysis high plasma 3-NT levels could indicate a significantly increased risk for nitrosative tissue damage in these patients. Kose et

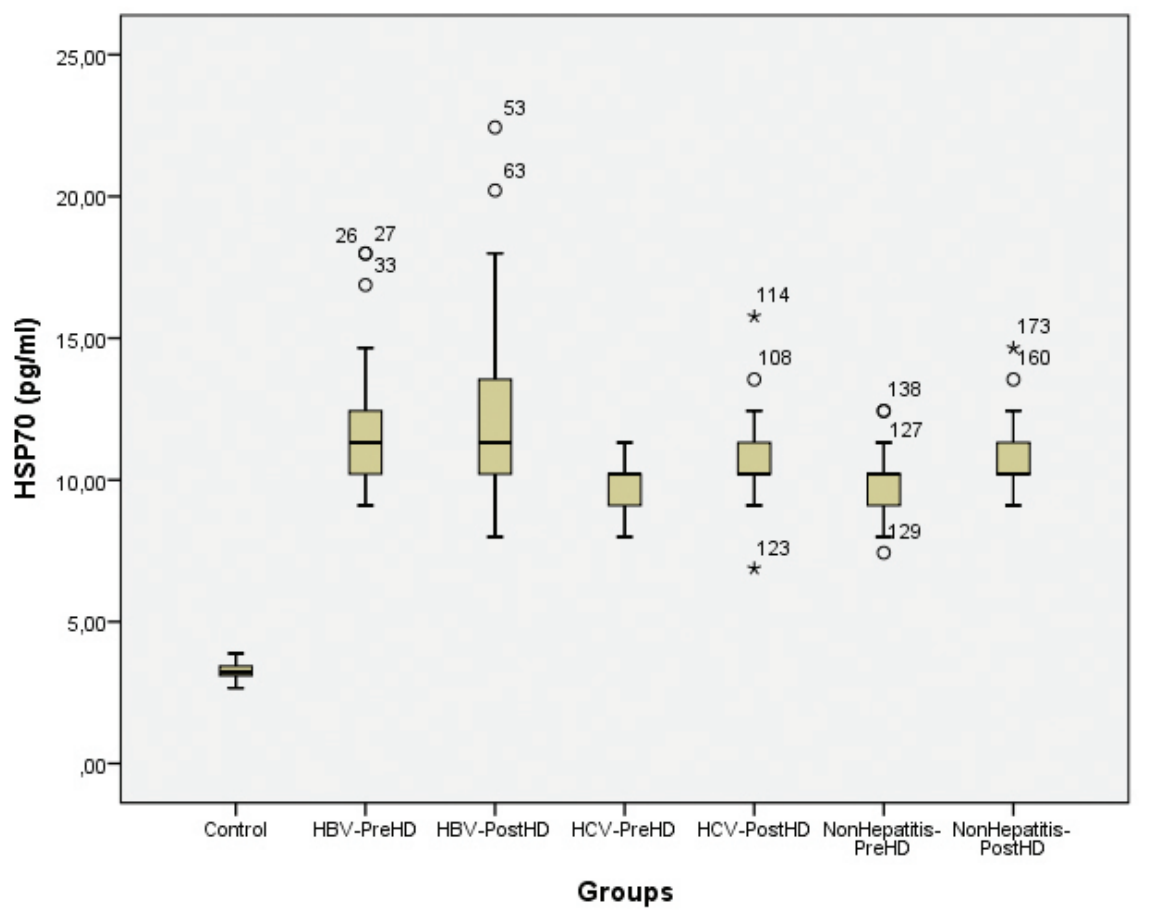

Figure 3. HSP-70 levels of non-hepatitis, hepatitis $B$ and hepatitis $C$ patients receiving hemodialysis treatment and control group 
al, in their study, indented to determine the effect of hemodialysis and peritoneal dialysis treatments on oxidative and nitrosative stress markers revealed that high presence of 3-NT levels pre and post hemodialysis indicate significantly increased the risk for nitrosative tissue damage in these patients (30). It was found in a study carried out by Proddi et al that 3-NT levels in CKD and ESRD patients were significantly higher compared to healthy subjects (31). In a study by Qian et al which aimed to investigate the relationship between the level of protein damage indicator $3 \mathrm{NT}$ and mortality in patients receiving treatment due to kidney damage. Therefore, 90-day mortality rates of patients treated for kidney damage and 3-NT levels were recorded and compared. The level of 3-NT in patients with kidney damage was found significantly higher compared to healthy control subjects. It was also found that high 3 -NT levels in patients are also proportional to high mortality rates (32). Oxidative stress is one of the potential biochemical mechanisms of chronic viral pathogenesis. In his study In an another study, Namiduru et al measured malondialdehyde, myeloperoxidase and nitrotyrosine levels in chronic HBV and HCV patients in order to determine the level of oxidative stress. No statistically significant difference between patients with hepatitis and control group was observed in nitrotyrosine levels. The data obtained from this study has shown that there is oxidative stability in patients with chronic viral disorders (33). In our study, 3 NT levels were found statistically significantly higher in pre dialysis of non-hepatitis, HBV and $\mathrm{HCV}$ patients receiving hemodialysis treatment statistically significantly higher than the control group. Despite the reduction in 3-NT levels post dialysis they still did not reach the value of healthy individuals. Considering the values obtained from the study, it has been established that protein oxidation caused by $3-\mathrm{NT}$ and a cytocidal effect was higher HCV patients among other patient groups. In recent years, although it has been known that TWEAK, a glycoprotein found in the TNF superfamily, has a relation with atherosclerosis, endothelial dysfunction and mortality in renal and non-renal patients, the results obtained vary from each other. Increased levels of TWEAK are observed in clinical conditions caused by inflammatory events, while TWEAK level decreases in atherosclerosis, which indicates that the event could be different depending on the interaction in receptor levels (34). In our study, the increase and reduction in TWEAK levels of $\mathrm{HBV}$ and $\mathrm{HCV}$ patients compared to the control are thought to be caused by receptor difference which plays a significant role in the viral interaction. Kralish et al in a study determined TWEAK levels in healthy control group, TWEAK levels in hemodialysis patients also in diabetic patients on hemodialysis therapy and found that TWEAK levels significantly reduced in diabetic patients receiving hemodialysis treatment and also concluded that TWEAK could be a risk factor for atherosclerosis (35). Yilmaz et al. studied how patients with non-diabetic chronic renal failure undergo changes in TWEAK levels in different stages and also investigated whether there is a relationship between TWEAK levels and endothelial dysfunction. It was found that as the stage of renal failure increases, there is an increase in endothelial dysfunction as opposed to the decrease in TWEAK level and it was also concluded that TWEAK is independent of endothelial dysfunction (36). In our study, it was observed that the high TWEAK value pre-dialysis, which is a marker of inflammation, decreased the following dialysis in HBV and non-infective patient groups, but it was determined not to be enough. As for HCV patients, while their pre dialysis TWEAK levels were lower compared to healthy subjects, these values increased post dialysis and passed the TWEAK values of healthy subjects. Inflammation in HCV patients was observed to increase rapidly with dialysis. Another parameter associated with oxidative stress is heat shock protein HSP70 and it can also be detected in diseases such as tissue, cell or serum levels of cardiovascular diseases, diabetes or diseases such as hyperlipidemia, and obesity (37). Yabunak et al found that HSP70 levels of diabetic patients in mononuclear cells which were measured by Western blot method was higher than in healthy controls, but stated that it has no connection with HbAlc and fasting blood glucose (38). In spite of various diseases in the literature to be working with a group of diseases with similar levels of HSP70, it was determined and found to be higher in the presence of oxidative stress. In the literature reviews done, although there was no study with similar disease groups, HSP70 levels were detected in some diseases and found to be higher in the presence of oxidative stress $(26,39,40)$. In our study, a statistically significant increase pre and post dialysis in HSP70 levels of the patient groups and the HSP70 levels belonging to the healthy control group was observed. However, a statistically significant change was determined between the groups.

\section{CONCLUSIONS}

Renal failure is a disease that manifests itself in the deterioration of the essential functions of the kidneys that cause damage to the individual at a significant level, which is accompanied by a decrease in glomerular filtration value. Although this damage, which occurs in the kidneys, is tried to be alleviated by dialysis treatment, it also increases the oxidative stress and immunity in the patients.

Viral diseases are frequently seen in patients undergoing hemodialysis treatment. Increased viral load in these patients increases the oxidative burden in the organism with renal failure.

In our study, 3-NT, TWEAK and HSP 70 values were higher in patients without hepatitis compared to the control group, indicating that oxidative stress and immunity increased in patients and that they could not be sufficiently reduced by dialysis treatment. In addition to dialysis, the presence of $\mathrm{HBV}$ alone and $\mathrm{HCV}$ alone in these 
patients affects different levels of oxidative stress and immunity in patients. The presence of HCV alone increased the levels of 3-NT and HSP in the patients and caused a decrease in the TWEAK values.

To prevent the increase of inflammation and oxidative stress in hemodialysis patients or to keep it under control, investigating certain parameters such as TWEAK, 3-NT and HSP70 from time to time is of great importance in terms of minimizing the level of risk for many diseases such as cardiovascular diseases.

Infection also increases the burden on oxidative stress and immunity system in these patients. This study emphasizes that the important of infection in dialysis patients who have a high mortality and morbidity rate.

Acknowledgements: This research was supported by the Science Research Department of Hitit University (Project no: FEF19003.14.001).

Authors' contributions: E Avci: Design, data collection, laboratory study, review of the manuscript; $M$ Geldi; laboratory study; G Alp Avci: Design, data collection, laboratory study, statistical analysis, editing of the manuscript prepared; S Coskun Cevher: Reviewing the final version of the manuscript.

Conflict of interest disclosure: The authors declare that they have no conflicts of interest for this work.

\section{REFERENCES}

1. LAZARUS JM, BRENNER BM 1998 Chronic renal failure. Harrison's principles of internal medicine, Fauci AC, Braunwald E, Issebacher KJ, Martin JB (ed) McGraw Hill Inc. 2: 1513-1519.

2. KAPLAN O, BAKICI MZ, ÇELIK C, KAYATAS M, CANDAN F 2013 Cumhuriyet Üniversitesi Araştırma ve Uygulama Hastanesi hemodiyaliz ünitesi hastalarının HBsAg ve anti HCV seropozitiflikleri. Viral Hepatitis Journal 19 (3): 126-130.

https://doi.org/10.4274/Vhd.88597

3. BERNIEH B, 2015 Viral hepatitis in hemodialysis: An update. J Transl Int Med. 3(3): 93-105.

https://doi.org/10.1515/jtim-2015-0018

4. EDEY M, BARRACLOUGH K, JOHNSON DW 2010 Review article: Hepatitis B and dialysis. Nephrology (Carlton) 15(2): 137-145. https://doi.org/10.1111/j.1440-1797.2009.01268.x

5. MOREIRA RC, LEMOS M., LONGUI CA, GRANATO C 2005 Hepatitis C and Hemodialysis, A Review. Brazil J Infect Dis 9(3): 269-275.

6. MOLOUGHNEY BW 2001 Transmission and postexposure management of bloodborne virus infections in the health care setting, Where are we now? CMAJ 165: 445-451.

7. HUANG CC 1997 Hepatitis inpatients with end-stage Renal Disease. J Gastrol Hepatol 12: 236-241.

https://doi.org/10.1111/j.1440-1746.1997.tb00506.x

8. PEREIRA BG 1999 Hepatitis C Infection in Dialysis, Acontinuing Problem. Artificial Organs 23: 51-60.

https://doi.org/10.1046/j.1525-1594.1999.06274.x

9. Centers for Disease Control and Prevention 2001 Recommendations for preventing transmission of infections among chronic hemodialysis patients Morbidity and Mortality Weekly Report (MMWR). 50(RR05): 1-43.

10. Kidney Disease 2008 Improving Global Outcomes. KDIGO clinical practice guidelines for the prevention, diagnosis, evaluation, and treatment of Hepatitis $\mathrm{C}$ in chronic kidney disease. Kidney Int. 73 (Suppl 109): 91-99.

11. GOLDBLUM SE, REED WP 1980 Host defenses and immunologic alterations associated with chronic hemodialysis. Ann Intern Med 93: 597. https://doi.org/10.7326/0003-4819-93-4-597

12. AKPOLAT T, UTAS C 2001 Hemodiyaliz Hekimi El Kitabı, Türk Nefroloji Dernegi Yayın Organı. 2. Ed. Kayseri, Anadolu Yayıncılık. 33-34.

13. SIRMATEL F 2008 The Seroprevalence of Hepatitis B and Hepatitis $\mathrm{C}$ in Hemodialysis Patients. Turkish Journal of Infection 22(1): $28-29$.

14. PARLAR E 2008 Diyaliz Hastalarının Nozokomiyal Enfeksiyon Kontrolü, Hastane Enfeksiyonları. Korunma ve Kontrol Sempozyum Dizisi 60: 121-129.

15. EVIRGEN Ö, MAHSERECI E, İNCI M 2010 The Evaluation of the Seroprevalence of HBV and HCV Infections in Patients with Hemodialysis in Hatay City and the Assessment of Antibody Response to Hepatitis B Vaccination. Viral Hepatit Dergisi 16(2): 57-63.

16. ÖZŞAHIN EA, YAZICI C, KÖSE K, UTAŞ C, TOKGÖZ B 2004 Malondialdehyde and Thiol Levels in Plasma of Hemodialysis Patients. EÜ Journal of Health Sciences 13 (2): 8-14.

17. ENGIN A, ALTAN N 2000 Effects of obstructive jaundice on the antioxidative capacity of human red blood cells. Turkish Journal of Hematology 30: 91-96.

https://doi.org/10.1163/15685590051130100

18. NOYAN T, BALAHAROĞLU R, KÖMÜROĞLU U 2005 The oxidant and antioxidant effects of 25-hydroxyvitamin D3 in liver, kidney and heart tissues of diabetic rats. Clinical and Experimental Medicine 5(1): 31-36.

https://doi.org/10.1007/s10238-005-0061-8

19. AVCI E, COŞKUN Ş, ÇAKIR E, KURT Y, OZGUR AKGUL E, BILGI C 2008 Relations between Concentrations of Asymmetric Dimethylarginine and Neopterin as Potential Risk Factors for Cardiovascular Diseases in Haemodialysis-Treated Patients. Renal Failure 30 (8): 784-790.

https://doi.org/10.1080/08860220802249009

20. ALTAN N, DINÇEL AS, KOCA C 2006 Diabetes mellitus ve oksidatif stress. Turkish Journal of Biochemistry 31(2): 51-56.

21. CANAUD B, CRISTOL JP, MORENA M 1999 Imbalance of oxidants and antioxidants in hemodialysis patients. Blood Purification Journal Contact 17: 99-106.

https://doi.org/10.1159/000014381

22. GÜLER M 2006 Kronik Hemodiyaliz Olgularında Sıkı Volüm Kontrolünün Bilişsel Fonksiyonlar, Oksidatif Stres ve İnflamasyon Belirteçlerine Olan Etkileri. (Ph.D. Thesis) (Turkey): Faculty of Medicine, University of Firat.

23. LOUGHREY CM, YOUNG IS, LIGHTBODY JH, McMASTER D, McNAMEE PT, TRIMBLE ER 1994 Oxidative stress in hemodialysis. International Journal of Medicine 27: 679-683.

24. KAYALI R, ÇAKATAY U 2004 Protein Oksidasyonunun Ana Mekanizmaları. Cerrahpaşa J Med. 35: 83-89.

25. TUTAR Y, OKAN S 2012 Heat shock protein 70 purification and characterization from Cyprinion macrastomus macrastomus and Garra rufa obtusa. Journal of Thermal Biology 37: 95-99. https://doi.org/10.1016/j.jtherbio.2011.11.002

26. PULUR A 2011 Preeklamptik Gebelerde Isı Şok Protein 70 (Heat Shock Proteın 70) Düzeylerinin İncelenmesi. (Ph.D. Thesis) (Turkey): Faculty of Medicine, University of Atatürk. 
27. VARAN HI, DURSUN B, DURSUN E, OZBEN T, SULEYMANLAR G 2010 Acute effects of hemodialysis on oxidative stress parameters in chronic uremic patients, Comparision of two dialysis membranes. International Journal of Nephrology and Renovascular Disease 3: 39-45.

28. ERDUR FM, TÜRKMEN K., KAYIKÇIOĞLU H, OZCICEK F, TOKER A, OZBEK O, TURK S, TONBUL HZ 2015 The Relationship between Oxidative Stress and Coronary Artery Calcification in Patients Undergoing Peritoneal Dialysis or Hemodialysis. Eur J Gen Med 12(1): 53-58. https://doi.org/10.15197/sabad.1.12.09

29. KOLEGANOVA N, PIECHA G, RITZ E, SCHIRMACHER P, MÜLLER A, MEYER HP, GROSS ML 2009 Arterial calcification in patients with chronic kidney disease. Nephrol Dial Transplant 24: 2488-2496. https://doi.org/10.1093/ndt/gfp137

30. KÖSE FA, SEZIŞ M, AKÇIÇEK F 2011 Oxidative and nitrosative stress markers in patients on hemodialysis and peritoneal dialysis. Blood Purification Journal Contact 32: 202-208. https://doi.org/10.1159/000328030

31. PIRODDI M, PALMESE A, PILOLLI F, AMORESANO A, PUCCI P, RONCO C, GALLI F 2011 Plasma nitroproteome of kidney disease patients. Amino Acids 40(2): 653-667. https://doi.org/10.1007/s00726-010-0693-1

32. QUIAN J, YOU H, ZHU Q, MA S, ZHOU Y, ZHENG Y, LIU J, KUANG D, GU Y, HAO C, DING F 2013 Nitrotyrosine level was associated with mortality in patients with acute kidney injury. PLoS ONE 8 (11): e79962. https://doi.org/10.1371/journal.pone.0079962

33. NAMIDURU ES, NAMIDURU M, TARAKÇIOĞLU M, TANRIVERDI M 2012 Levels of Malondialdehyde, Myeloperoxidase and Nitrotyrosine in Patients with Chronic Viral Hepatitis B and C. Adv Clin Exp Med 21(1): 47-53.

34. BLANCO-COLIO LM, MARTÍN-VENTURA JL, MUNOÓZGARCÍA B, ORBE J, PÁRAMO JA, MICHEL JB, ORTIZ A,
MEILHAC O, EGIDO J 2007 Identification of soluble tumor necrosis factor-like weak inducer of apoptosis (sTWEAK) as a possible biomarker of subclinical atherosclerosis. Arteriosclerosis, Thrombosis and Vascular Biology 27: 916-922. https://doi.org/10.1161/01.ATV.0000258972.10109.ff

35. KRALISCH S, ZIEGELMEIER M, BACHMANN A, SEEGER J, LÖSSNER U, BLÜHER M, STUMVOLL M, FASSHAUER M 2008 Serum levels of the atherosclerosis biomarker sTWEAK are decreased in type 2 diabetes and end-stage renal disease. Atherosclerosis 199 (2): 440-444.

https://doi.org/10.1016/j.atherosclerosis.2007.10.022

36. YILMAZ MI, CARRERO JJ, ORTIZ A, MARTÍN-VENTURA JL, SONMEZ A, SAGLAM M, YAMAN H, YENICESU M, EGIDO J, BLANCO-COLIO LM 2009 Soluble TWEAK plasma levels as a novel biomarker of endothelial function in patients with chronic kidney disease. Clinical Journal of the American Society of Nephrology 4: 1716-1723.

https://doi.org/10.2215/CJN.02760409

37. ARMUTCU F, ATAYMEN M, ATMACA H, GUREL A 2008 Oxidative Stress Markers, C-Reactive Protein and Heat Shock Protein 70 Levels In Subjects With Metabolic Syndrome. Clinical Chemistry and Laboratory Medicine 46: 785-790. https://doi.org/10.1515/CCLM.2008.166

38. YABUNAKA N, OHTSUKA Y, WATANABE İ 1995 Elevated levels of heat-shock protein 70 (HSP70) in the mononuclear cells of patients with non-insulin-dependent diabetes mellitus. Diabetes Research and Clinical Practise 30: 143-147. https://doi.org/10.1016/0168-8227(95)01151-X

39. HOOPER P 2003 Diabetes, nitric oxide, and heat shock protein. Diabetes Care. 26 (3): 951-952. https://doi.org/10.2337/diacare.26.3.951

40. KALMAR B, GREENSMITH L, 2009. Induction of heat shock proteins for protection against oxidative stress. Advanced Drug Delivery Reviews 61(4): 310-318.

https://doi.org/10.1016/j.addr.2009.02.003 